\title{
Hepatitis B and C in the Syrian Arab Republic: a review
}

H. Bashour ${ }^{7}$ and G. Muhjazi ${ }^{2}$

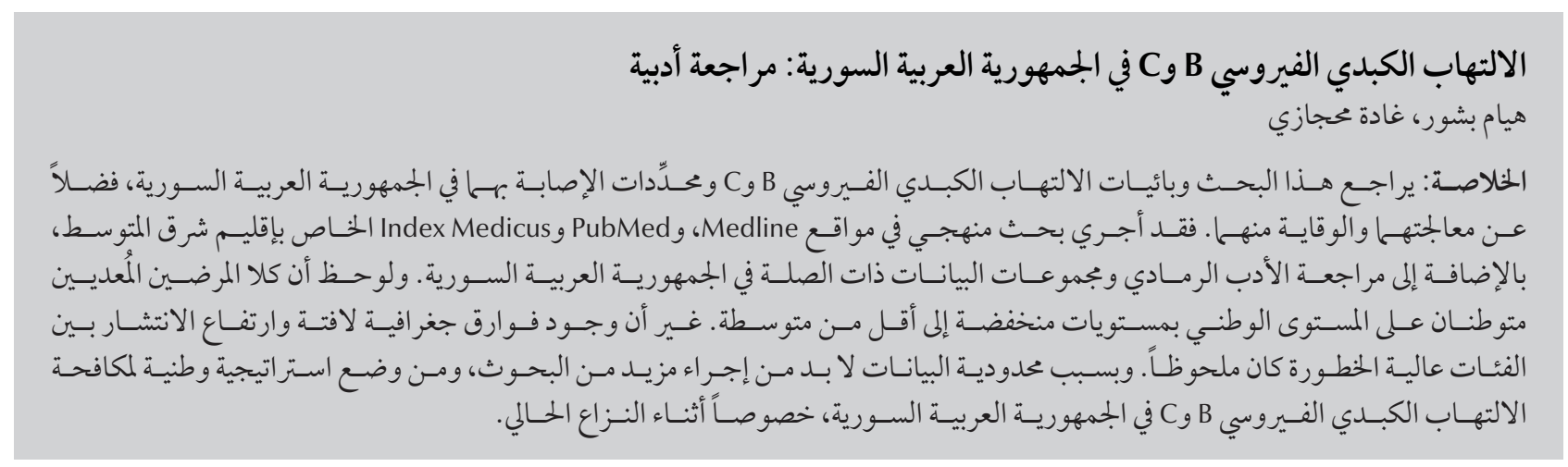

ABSTRACT This paper reviews the epidemiology and determinants of hepatitis B and C in the Syrian Arab Republic as well as their treatment and prevention. A systematic search of Medline, PubMed and Index Medicus for the Eastern Mediterranean Region was carried out in addition to a review of grey literature and relevant datasets in the Syrian Arab Republic. Low to low-intermediate levels of endemicity of both infections were noted at the national level. However, striking geographic differences and high prevalence among high-risk groups were noticeable. As a result of data limitations, further research is needed, and a national control strategy to combat hepatitis B and C in the Syrian Arab Republic should be developed, especially during the current conflict.

\section{Hépatites B et C en République arabe syrienne : analyse}

RÉSUMÉ La présente étude examine l'épidémiologie et les déterminants des hépatites B et C en République arabe syrienne, ainsi que leur traitement et leur prévention. Une recherche systématique dans Medline, PubMed et dans I'Index Medicus de la Région de Méditerranée orientale a été menée, en plus d'un examen de la littérature grise et d'un ensemble de données pertinentes en République arabe syrienne. Des niveaux d'endémicité faibles à intermédiaires pour les deux infections ont été constatés à l'échelle nationale. Néanmoins, des disparités géographiques frappantes ainsi qu'une prévalence élevée parmi les groupes à haut risque étaient notables. Du fait du nombre limité de données, une recherche plus approfondie est nécessaire, et une stratégie de lutte nationale pour combattre les hépatites B et C en République arabe syrienne doit être élaborée, en particulier dans le contexte de conflit actuel. 


\section{Introduction}

The global epidemic of hepatitis B virus (HBV) and hepatitis $\mathrm{C}$ virus ( $\mathrm{HCV}$ ) is a serious public health problem worldwide, and chronic hepatitis $B$ and $C$ are among the leading causes of preventable death. The global burden of disease caused by acute hepatitis B and C and by cancer and cirrhosis of the liver is high ( $\sim 2.7 \%$ of all deaths) and is forecast to increase over the next 2 decades (1). Worldwide, there is major concern about the cost of treating chronic cases of hepatitis B and C $(2,3)$.

According to the global review of hepatitis B and C in 2013, the Syrian Arab Republicis classified as having high prevalence of hepatitis $\mathrm{C}$ and low-intermediate prevalence of hepatitis $B(4,5)$. However, a more recent and up-to-date systematic review by Chemaitelly and colleagues indicated that HCV prevalence is $<1 \%(6)$.

Prior to the current conflict, the Syrian Arab Republic had a well-established healthcare system for both curative and preventive services, with nearly complete coverage of the population, as well as a strong private sector. An estimated $7.8 \%$ of the government budget was allocated for health, and the total health expenditure accounted for $\sim 4.5 \%$ of the gross domestic product (7).

Since 2011, the conflict has adversely affected the health sector (8). The risk of epidemic-prone diseases increased because of population displacement, disruption of health services, reduced vaccination coverage, shortage of medicines, and deterioration of water and sanitation systems. Furthermore, the public health routine surveillance system deteriorated because of disruption to health facilities, insecurity, and emigration of health professionals $(9,10)$.

Better knowledge of HBV and HCV epidemiology and its determinants may contribute to an effective control strategy. The aims of this review are to provide a comprehensive update on the epidemiology of HBV and HCV in the Syrian Arab Republic, and to foster discussion about a potential prevention and control strategy, especially during the current conflict.

\section{Methods}

A mix of methods was used for the purpose of this review. We searched Medline, PubMed and Index Medicus for the Eastern Mediterranean Region for articles in English and Arabic languages relating to $\mathrm{HBV}$ and $\mathrm{HCV}$ epidemiology, prevention and treatment in the Syrian Arab Republic, using the search terms shown in Box 1. The main inclusion criterion was relevance to the purpose of this review. Data were abstracted by one of the authors using a data abstraction form which included: Study (first author and year); Type of study; Study site(s) and setting; Enrolment and follow-up periods; Number of subjects; Typology; Outcome; Results; Crude rate; Adjusted rate; Other; and Quality. The extracted data were then synthesized in accordance with the purpose of this review of hepatitis $B$ and C in the Syrian Arab Republic.

A review of the official surveillance data on hepatitis B and C in the Syrian Arab Republic was conducted, for which the main source was the national reporting system of infectious diseases (Syrian Ministry of Health; www.moh. gov.sy). Other sources included the aggregated data from blood banks ( 26 blood transfusion centres that are affiliated to the General Organization for Blood and Medical Products, Damascus), as well as the aggregated data from the 7 premarital clinics. Data from the

\section{Box 1 MEDLINE search strategy}

Standard search

Syria

Hepatitis B/

Hepatitis C/

Combined search with epidemiology, prevention, and treatment and care

Epidemiology

Prevalence/

Incidence/

Morbidity/

Mortality/

Disease transmission, infectious/

\section{Prevention}

Vaccination

Primary prevention/

Treatment and care

Results were limited to human studies and reviews published in English and Arabic, without any date restriction 
hepatitis treatment centres affiliated to the Syrian Ministry of Health $(\mathrm{MoH})$ were also reviewed. A search of grey literature was carried out for all relevant national reports, including serological surveys, in the Syrian Arab Republic. We performed a search of the database of Masters degree theses submitted to Damascus University Faculties of Medicine and Pharmacy from 2009 to 2015. The websites of other national universities were also searched for theses on hepatitis B and C.

\section{Results}

\section{Search results}

Twenty-two of 34 articles identified in our search were included in this review. Twelve articles were excluded because they were assessed as not relevant. All relevant key national reports $(n=4)$, datasets $(n=5)$ and Masters theses ( $n$ $=9$ ) were also included. Masters theses that have been published (all but 1) were reviewed as articles and not as full theses.

\section{Epidemiology of hepatitis $B$ and $C$ in the Syrian Arab Republic}

\section{Prevalence}

In 2004, the Syrian MoH in cooperation with the Central Bureau of Statistics carried out a large serological survey on a random cluster sample with 528 clusters and 3168 individuals (11). The seroprevalence of hepatitis $\mathrm{C}$ was $2.8 \%$ as indicated by HCV antibodies and $5.6 \%$ for hepatitis B as indicated by HBV surface antigen (HBsAg). There was a clear regional variation in the prevalence of hepatitis B and C. Higher prevalence was mainly reported in two governorates in the northern and eastern parts of the country. In Aleppo governorate in the north, the seroprevalence was $10.14 \%$ for hepatitis C and $10.5 \%$ for hepatitis B. In Hassakeh governorate in the north-east, the seroprevalence was $10.6 \%$ for hepatitis B. Suspected determinants of high prevalence of hepatitis $B$ and $C$ included poor infection control practices.

Another serological survey was carried out by the Syrian $\mathrm{MoH}$ in 2005-2006 in two governorates in the north-east, Hassakeh and Deir Zour (Syrian MoH, unpublished data, 2005). The survey covered a random sample of 1217 individuals in Hassakeh and 763 in Deir Zour. The seroprevalence of hepatitis $C$ was $1.56 \%$ in Hassakeh and $2.1 \%$ in Deir Zour. The prevalence of hepatitis B antibodies was $32.2 \%$ in Hassakeh and 37.4\% in Deir Zour.

\section{Incidence}

There are no available data on the incidence of HBV and HCV infection in the Syrian Arab Republic. Communicable disease law mandates the notification of communicable diseases in the country (Decree no. 7, 2007). Notification of suspected cases of acute hepatitis (as defined in the Communicable Diseases Surveillance guidelines issued by the $\mathrm{MoH}$ in 2010) is done by both private and public sectors (12). Suspected acute hepatitis cases are not followed up by any laboratory tests, meaning that all cases of acute hepatitis are undifferentiated. The Early Warning and Response System (EWARS) is a weekly reporting system established during the current conflict, which also reports on acute jaundice syndrome but, again, it is not supported by laboratory confirmation $(13,14)$.

\section{Screening at blood banks}

According to the guidelines issued by the General Organization for Blood and Medical Products, all blood donated at Syrian blood banks is screened for HIV, $\mathrm{HBV}, \mathrm{HCV}$, syphilis and cytomegalovirus (15). Figure 1 shows the proportion of blood samples positive for $\mathrm{HBV}$ and HCV in the blood banks in Syria in 2003-2014. In 2014, 1.1\% of blood was positive for HBV compared with $0.4 \%$ for HCV. The decreasing trend in hepatitis B positivity may be linked to the continuous hepatitis $B$ vaccination programmes, as described later. It was clear that the highest positivity for HBV and HCV was seen in the northern and eastern regions. For example, in 2012, the proportion of blood positive for HBV was $2.2 \%$ in the northern region and $2.54 \%$ in the eastern region as compared to $0.78 \%$ in the coastal region (15). A similar trend was observed for $\mathrm{HCV}$, where a high prevalence rate was noted in the northern region $(0.53 \%$ in 2012) as compared to $0.25 \%$ in the coastal region.

\section{Screening at premarital clinics}

A national policy of premarital screening was issued by the Syrian $\mathrm{MoH}$ in cooperation with the Syrian Medical Syndicate and was adopted by the Ministry of Justice for marriage registration (Law 3/15/759 in 2007). The premarital screening of genetic and infectious disease is thus mandatory. Seven clinics were established in most Syrian governorates, namely Homs, Idleb, Hama, Lattakia, Tartous, Daraa and Aleppo. In 2011, the prevalence in premarital clinics was $0.11 \%$ for $\mathrm{HCV}$ and $1.49 \%$ for $\mathrm{HBV}$ as reported to the $\mathrm{MoH}$, and in 2014 it was $0.05 \%$ and $0.68 \%$, respectively $(\mathrm{MoH}$, personal communication, 2015).

\section{High-risk groups}

Several published studies conducted in the Syrian Arab Republic have identified the high-risk groups with higher prevalence of infections.

Hepatitis B and C are common in paediatric hospitals in Damascus among children with haematological disease with repeated blood transfusion. A study conducted in 2000 at the University Children's Hospital on 75 children with diagnosed haematological disease and repeated blood transfusion showed that HCV antibody was positive among $13.3 \%$ of the sample and $5.3 \%$ of the children were positive for HBsAg (16).

Othman and Monem (2001) reported an overall prevalence of $\mathrm{HCV}$ 
antibody of $48.9 \%$ among 139 haemodialysis patients from Al Mouassat Hospital and Kidney Surgical Hospital in Damascus (17). The prevalence was 24.4\% in Al Moussat Hospital and 88.6\% in Kidney Surgical Hospital. A sample from medical staff showed a prevalence of $5.8 \%$.

Othman and colleagues (2001) reported a prevalence of $\mathrm{HBs} A g$ positivity of $5 \%$ among health workers, $3 \%$ among haemodialysis staff, $8 \%$ among dentistry staff and 13\% among surgery staff in Damascus (18). The prevalence of $\mathrm{HCV}$ antibodies among the healthcare workers was $3 \%$.

Othman and Monem (2002) reported a prevalence of HCV antibodies of $60.5 \%$ among injectable drug users, $1.96 \%$ among sex workers and $0.95 \%$ among blood donors (19). HBsAg positivity was $5.3 \%$ among injectable drug users, $10.8 \%$ among sex workers and $3.8 \%$ among blood donors.

\section{Treatment for hepatitis B and C}

Treatment for hepatitis B and C in the Syrian Arab Republic is provided free of charge by the $\mathrm{MoH}$ to all patients with chronic hepatitis. The cost of treatment of chronic hepatitis B is estimated at 700000 Syrian pounds (US\$ 11 112) per patient annually (20). Seven centres were established for the treatment of chronic hepatitis and are located in Damascus Hospital and Ibn Nafees Hospital in Damascus), and five more centres were established in the governorates of Homs, Hama, Lattakia, Aleppo and Deir Zour. The drugs used according to the national guidelines are interferon alpha-2b and entecavir or tenofovir for chronic hepatitis B, and pegylated interferon with ribavirin for chronic hepatitis $C(21)$.

In 2012, 523 cases of hepatitis B and 480 cases of hepatitis C were treated, compared with only 124 cases of hepatitis $\mathrm{B}$ and 113 cases of hepatitis $\mathrm{C}$ in 2014 (MoH, personal communication). The lower number of treated patients in 2014 can be explained by the shortage of medicines and lack of access by patients during the years of conflict.

\section{Knowledge and awareness related to hepatitis $B$ and $C$}

Awareness of the general public is one of the major factors in preventing hepatitis B and C. In 2014, Ibrahim and Idris showed that 93 1st-year medical students in a private university had poor knowledge and lack of awareness about hepatitis B compared to the 5th-year medical students (22). Most of the 1styear students (98.44\%) were not vaccinated against hepatitis B. Furthermore, Yacoub et al. (2010) noted that 23.4\% of 246 healthcare workers in Aleppo University were never vaccinated (23).

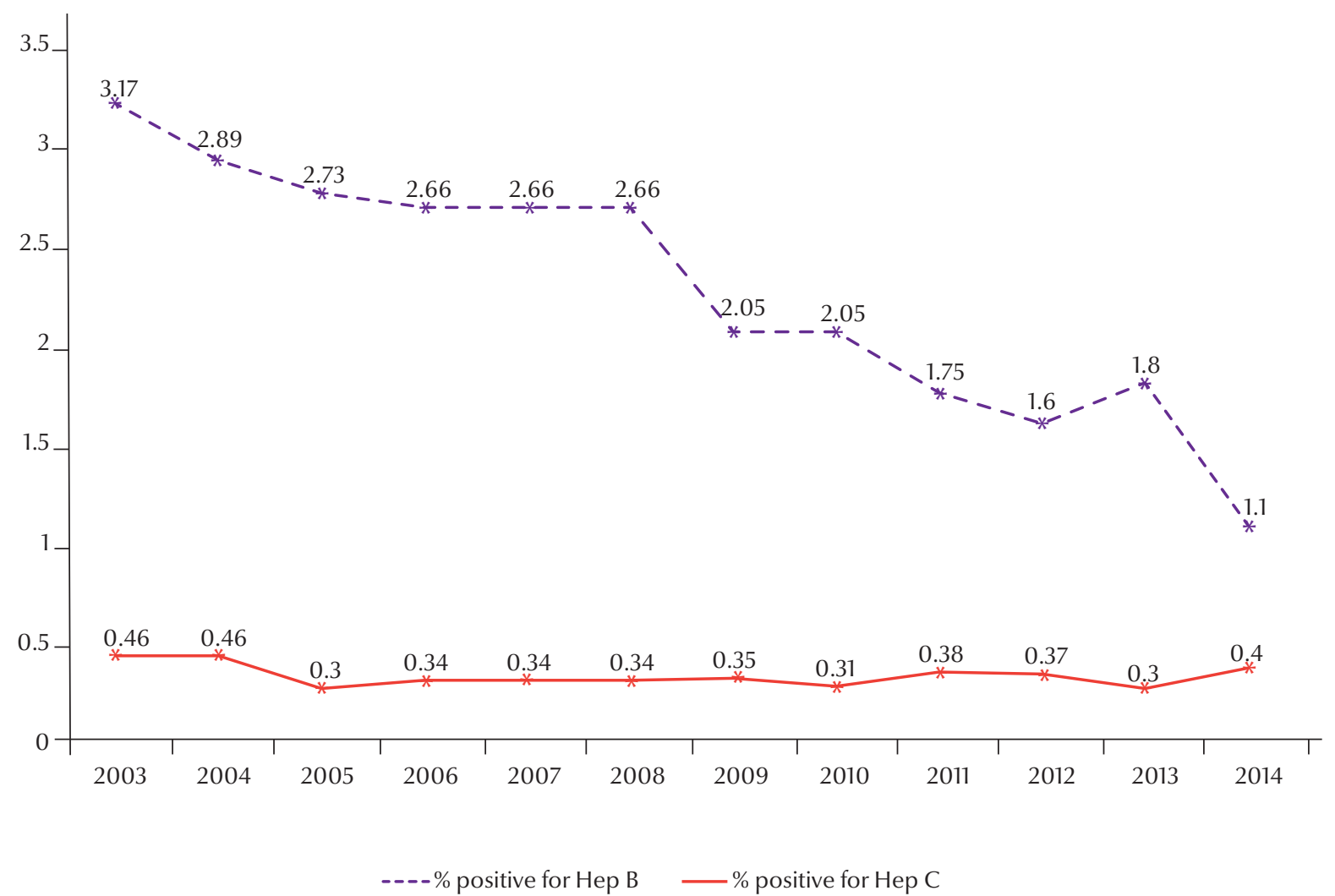

Figure 1 Proportion positive for hepatitis B virus and hepatitis C virus in the blood banks (2003-2014) as reported to the Syrian Ministry of Health 


\begin{tabular}{|c|c|c|}
\hline Year & Hepatitis B vaccine coverage (\%) & HBV prevalence (\%) at blood banks \\
\hline 1995 & 74 & - \\
\hline 2000 & 83 & - \\
\hline 2005 & 83 & 2.73 \\
\hline 2006 & 83 & 2.66 \\
\hline 2007 & 83 & 2.66 \\
\hline 2008 & 83 & 2.66 \\
\hline 2009 & 84 & 2.05 \\
\hline 2010 & 84 & 2.05 \\
\hline 2011 & 66 & 1.75 \\
\hline
\end{tabular}

WHO/UNICEF. Immunization summary. A statistical reference containing data through 2011 (http://www. unicef.org/immunization/files/EN-ImmSumm-2013.pdf, accessed 3 May 2016).

Vaccination against hepatitis B

Hepatitis B is preventable with currently available safe and effective vaccines. In the Syrian Arab Republic, hepatitis B vaccine was added to the national vaccination programme in 1993. The vaccination coverage among the children studied in the 2009 PAPFAM survey of 24883 households was $88 \%$ for the 2nd dose and $82 \%$ for the 3 rd dose of hepatitis B vaccine (24). However, there are no estimates of infants who received the 1st dose of hepatitis B vaccine within $24 \mathrm{~h}$ of birth. This is, of course, a major challenge, as home delivery is still common in the Syrian Arab Republic (21.8\% of deliveries according to the PAPFAM survey) (24). Barriers to child vaccination have been studied at the national level by the Syrian $\mathrm{MoH}$ (25). The barriers include lack of awareness and sometimes fear of vaccination, although there were no barriers specific to hepatitis B vaccination compared to those for other vaccination.

There is no study of the impact of hepatitis B vaccination in the Syrian Arab Republic; however, there was a clear decreasing trend in HBV prevalence in blood banks after introduction of hepatitis B vaccine (Table 1 ).

No national data exist on the vaccination of health care workers in the Syrian Arab Republic, although vaccination is practiced at hospitals and health facilities as well as medical, dentistry and nursing schools in universities. All vaccination of healthcare workers is administered at health facilities and universities, and is provided free of charge.

\section{National policies on hepatitis in the Syrian Arab Republic}

The national policies on hepatitis in the Syrian Arab Republic were extensively reviewed by WHO (20). There is no national strategy to control hepatitis B and C in the Syrian Arab Republic. However, there are public awareness campaigns including World Hepatitis Day. There is adequate laboratory capacity at the national level to support investigation of viral hepatitis outbreaks in the Syrian Arab Republic. There is no national public health research agenda for viral hepatitis, although Masters degree students occasionally research the disease.

There are no national policy/ guidelines for preventing hepatitis $\mathrm{B}$ and $\mathrm{C}$ infection in healthcare settings, but there is a national policy on injection safety in healthcare settings. A national infection control policy for blood banks is available. Hepatitis $\mathrm{B}$ and $\mathrm{C}$ tests are free of charge and compulsory for blood donors, couples planning to marry, patients on haemodialysis, and those who receive frequent blood transfusions.

\section{Discussion}

This review of hepatitis B and C prevalence, prevention and treatment provides a comprehensive description of the epidemiology of the disease in the Syrian Arab Republic. It highlights the scale of the hepatitis B and C burden at the national level. The prevalence of both infections is low among blood donors, however, the 2004 populationbased serological survey indicated that the prevalence of HBV is of low-intermediate level and that of $\mathrm{HCV}$ is low. The prevalence of both infections is lower than that reported in other countries in the Arabic-speaking world $(6,26)$.

However, the high prevalence of $\mathrm{HBV}$ and HCV in the northern and eastern regions of the Syrian Arab Republic is worth noting. Although the 2004 serological survey hypothesized that it was related to poor infection control, this needs to be properly investigated (11). Furthermore, those two regions are currently not fully accessible by the $\mathrm{MoH}$ as a result of the ongoing conflict. The critical security and economic situations in the country add many challenges to the implementation of proper infection control and hygienic practices $(9,10)$.

The prevalence of HCV is high among high-risk groups in the Syrian Arab Republic; mainly those with haematological diseases with frequent blood transfusion, haemodialysis patients and injectable drug users. Chemaitelly and colleagues also reported a high prevalence of HCV among highrisk populations in the Syrian Arab Republic compared to other neighbouring countries (6).

There are no incidence data for $\mathrm{HBV}$ and HCV from the Syrian Arab Republic, but using prevalence figures from blood bank screening is a possible proxy. It is noticeable that there has been an overall decline in the prevalence of $\mathrm{HBV}$; presumably because 
of infant and childhood vaccination programmes.

Although all chronic cases of hepatitis B and C are treated by the Syrian $\mathrm{MoH}$ using public funds, the choice of treatment deserves further guidance. The study by Habbal and Monem (2012) on 50 patients with chronic hepatitis B in 2008-2010 demonstrated the dominance of genotype D in the Syrian Arab Republic, which is consistent with its high prevalence (27). Antaki and colleagues reported similar findings in 2010 (28). Habbal and Monem (27) argued that, despite the reported association of genotype $\mathrm{D}$ with poor response to interferon-based therapeutic regimens, interferon alpha is routinely prescribed as the first-line therapy in hepatitis B in the Syrian Arab Republic, according to the national guidelines (21). Similar arguments are applicable to the treatment of chronic $\mathrm{HCV}$, in which genotype 5 has been reported $(29,30)$.
The main limitation of this review is that it was based on a small number of published articles from the Syrian Arab Republic and on routine data with inherent problems. Data from blood banks, premarital clinics and treatment centres are shared by the $\mathrm{MoH}$, but are usually not published. Data from blood banks on apparently healthy populations may underestimate $\mathrm{HBV}$ and HCV prevalence in the population at large. Variations in the coverage and quality of existing research as well as the problems of routine data create uncertainty around many current estimates. Improved and more complete data and reporting are needed to estimate better the scale of the problem.

In conclusion, this review indicates that hepatitis B and C pose a key challenge to public health in the Syrian Arab Republic. The high prevalence in some geographic areas of the country warrants further investigation. Also, the high prevalence among some high-risk populations such as the haemodialysis patients also deserves attention in the coming national control strategy for hepatitis B and C in the Syrian Arab Republic. The ongoing work on the national strategy needs to tackle the issue of data limitations, but also needs to be responsive to the current crisis in the country, where the emergency situation further complicates the picture.

\section{Acknowledgements}

We acknowledge the support of the following colleagues: Dr Ghatfan Al Shawa, Dr Ahmed Dmeirya, Dr Hani Lahham and Dr Amer Al Tibi, and Professor Fawza Monem. The full support of Ms Elizabeth Hoff of the WHO Country Office in Damascus is appreciated. We are indebted to Dr Nizar Abazid for editing this manuscript.

Funding: This research was funded by the WHO Country Office, Syrian Arab Republic.

Competing interests: None declared.

\section{References}

1. Prevention \& control of viral hepatitis infection. Framework for global action. WHO/HSE/PED/HIP/GHP 2012.1. Geneva: World Health Organization; 2012.

2. Yang BM, Kim DJ, Byun KS, Kim HS, Park JW, Shin S. The societal burden of HBV-related disease: South Korea. Dig Dis Sci. 2010 Mar;55(3):784-93. PMID:19333757

3. González-Grande R, Jiménez-Pérez M, González Arjona C, Mostazo Torres J. New approaches in the treatment of hepatitis C. World J Gastroenterol. 2016 Jan 28;22(4):1421-32. PMID:26819511

4. Centers for Disease Control and Prevention. CDC Health Information for International Travel 2016 (http://www.cdc. gov/travel/page/yellowbook-home-2014, accessed 1 April 2016).

5. Mohd Hanafiah K, Groeger J, Flaxman AD, Wiersma ST. Global epidemiology of hepatitis $C$ virus infection: new estimates of age-specific antibody to HCV seroprevalence. Hepatology. 2013 Apr;57(4):1333-42. PMID:23172780

6. Chemaitelly H, Chaabna K, Abu-Raddad LJ. The epidemiology of hepatitis $\mathrm{C}$ virus in the Fertile Crescent: systematic review and meta-analysis. PLoS One. 2015 Aug 21;10(8):e0135281. PMID:26296200

7. National health expenditure survey. Damascus: Syrian Ministry of Health in collaboration with European Union; 2010.

8. Alwan A. The cost of war. Commentary. Media centre. WHO Regional Office for the Eastern Mediterranean, 6 November 2015 (http://www.who.int/mediacentre/commentaries/warcost/en/, accessed 1 April 2016).
9. World Health Organization Regional Office for the Eastern Mediterranean. Syrian Arab Republic. WHO response to the conflict in Syria. Situation report \#4, 15 June 2014 (http://www.emro.who.int/images/stories/syria/SituationReport_20140615.pdf?ua=1, accessed 1 April 2016).

10. Syrian Center for Policy Research, United Nations Relief and Works Agency, United Nations Development Programme. Syria: war on development: socioeconomic monitoring report of Syria. Second quarterly report April-June 2013 (http://www. unrwa.org/sites/default/files/md_syr-rprt_q2fnl_251013.pdf, accessed 1 April 2016).

11. Karim M, Laham H. Prevalence of viral hepatitis B and C in Syria. Syrian Epidemiol Bull. 2008; 3:10-11.

12. [The national guide for communicable disease surveillance]. Damascus: Syrian Ministry of Health; 2011 [in Arabic].

13. Muhjazi G, Bashour H, Abourshaid N, Lahham H. An early warning and response system for Syria. Lancet. 2013 Dec 21;382(9910):2066. PMID:24360384

14. EWARS weekly bulletins. Syrian Arab Republic. WHO Regional Office for the Eastern Mediterranean (http://www.emro.who. int/syr/publications-other/ewars-weekly-bulletin-2014.html, accessed 1 April 2016)

15. Al Assaad University Hospital. [Blood screening at blood banks in Syria]. Paper presented at a local conference on hepatitis, 2015 [in Arabic]

16. Monem F. Prevalence of hepatitis $C$ virus among hematological disease children in pediatric hospital in Damascus. Arab J Pharm Sci. 2000;1(7):59-64 
17. Othman B, Monem F. Prevalence of antibodies to hepatitis C virus among hemodialysis patients in Damascus, Syria. Infection. 2001 Oct;29(5):262-5. PMID:11688903

18. Othman BM, Monem FS. Prevalence of hepatitis C virus antibodies among health care workers in Damascus, Syria. Saudi Med J. 2001 Jul;22(7):603-5. PMID:11479642

19. Othman BM, Monem FS. Prevalence of hepatitis C virus antibodies among intravenous drug abusers and prostitutes in Damascus, Syria. Saudi Med J. 2002 Apr;23(4):393-5. PMID:11953762

20. Global policy report on the prevention of and control of viral hepatitis in WHO member states. Geneva: World Health Organization; 2013.

21. Syrian Working Group for the Study of Viral Hepatitis. [Management of hepatitis B national guidelines]. 3rd ed. Syria: Syrian Society of Gastroenterology; 2006 [in Arabic].

22. Ibrahim $\mathrm{N}$ and Idris $\mathrm{A}$. Hepatitis B awareness among medical students and theirvaccination status at Syrian Private University. Hepat Res Treat. 2014;2014:131920. doi: 10.1155/2014/131920.

23. Yacoub R, Al Ali R, Moukeh G, Lahdo A, Mouhammad Y, Nasser M. Hepatitis B vaccination status and needlestick injuries among healthcare workers in syria. J Glob Infect Dis. 2010 Jan;2(1):28-34. PMID:20300414

24. [Reasons for under vaccination among Syrian children. Damascus]. Damascus: Syrian Ministry of Health; 2009 [in Arabic].
25. [Family Health Survey]. Damascus: Syrian Central Bureau of Statistics in collaboration with the League of Arab States; 2010 [in Arabic].

26. Daw MA, Dau AA. Hepatitis C virus in Arab world: a state of concern. ScientificWorldJournal. 2012;2012:719494. 10.1100/2012/719494 PMID:22629189

27. Habbal W, Monem F. Rethinking therapeutic decisions for hepatitis B infection in Syria: insights into molecular monitoring. J Infect Dev Ctries. 2012 10 19;6(10):744-7. PMID:23103897

28. Antaki N, Haffar S, Ali Deeb S, Assaad F, Abou Harb R, Zeibane N, et al.; Syrian Working Group for the Study of Viral Hepatitis. High prevalence of HBV genotype D in Syria and the clinical characteristics of hepatitis B e antigen-negative chronic hepatitis B. Epidemiol Infect. 2010 Jan;138(1):40-4. PMID:19538827

29. Antaki N, Craxi A, Kamal S, Moucari R, Van der Merwe S, Haffar $S$, et al. The neglected hepatitis $C$ virus genotypes 4, 5 and 6 : an international consensus report. Liver Int. 2010 Mar;30(3):34255. PMID:20015149

30. Antaki N, Haddad M, Kebbewar K, Abdelwahab J, Hamed O, Aaraj R, et al.; Syrian Working Group for the Study of Viral Hepatitis. The unexpected discovery of a focus of hepatitis C virus genotype 5 in a Syrian province. Epidemiol Infect. 2009 Jan;137(1):79-84. PMID:18346288 